\title{
An Empirical Study on The Socio-Economic Conditions of the Plantation Workers in the Tea Industry of Darjeeling
}

\author{
Pratima Chamling Rai
}

Department of Economics, Balurghat College and Research Scholar, Raiganj University, West Bengal, India

Corresponding author: pratimachamlingrai84@gmail.com

\begin{abstract}
Tea cultivation occupies a place of pride in the Darjeeling hills. The development of the district has been driven by the growth of the tea industry. Nevertheless, this industry is presently in the grip of a mounting crisis. The Darjeeling tea industry has been passing through a period of stagnation. The existing tea estates experience frequent labour conflicts, and some have been locked out for considerable periods. As the tea workers are dependent solely on their wage earnings, the sufferings of workers have increased driving some of them even to suicide. This gives us a clear picture about the grim situation that confronts workers in the Darjeeling tea estates. The dimension of the structural readjustment that is needed within the tea industry to cope with them needs to be analysed immediately in protecting the rights of plantation workers and in equipping them for work and struggle through new livelihood strategies. Hence, the empirical study on the socio-economic conditions of the workers on the tea plantations would help us to understand their problems, while protecting their interests and provide an immediate help to seek better lookout for the condition of tea plantation workers in the hills before their inefficiency may turn into stagnation of the Tea Industry in Darjeeling.
\end{abstract}

Keywords: Socio-economic, Plantation Workers, Tea Estate

Tea cultivation occupies a place of pride in the Darjeeling hills. The development of the district has been driven by the growth of the tea industry. The tea industry has also contributed to the growth of the regional economy, because of its high quality standards and its high exportability. Apart from directly employing a vast number of plantation workers, the tea industry also provides indirect employment to a vast number of other persons in transport establishments, warehouses, hotels, schools, hospitals, trading firms and agricultural input-manufacturing units. This secondary employment is estimated to be of the same magnitude as the primary employment within the tea industry, hence lessening the burden of unemployment in the region. 
Nevertheless, the Darjeeling tea industry is presently in the grip of a mounting crisis. The existing tea estates will be obsolete within 50 years unless remedial steps are taken immediately. The best varieties of China tea bushes were planted in the Darjeeling hills before 1863 and there has been little replanting since then. The challenges to worker movements call for new approaches and new methods of cooperation with other social institutions. Current economic, social and political transformations within India imply new trade union roles in protecting the rights of plantation workers and in equipping them for work and struggle through new livelihood strategies.

The Darjeeling tea industry has been passing through a period of stagnation. The existing tea estates experience frequent labour conflicts, and some have been locked out for considerable periods. As the tea workers are dependent solely on their wage earnings, the sufferings of workers have increased driving some of them even to suicide. This gives us a clear picture about the grim situation that confronts workers in the Darjeeling tea estates. There is a need to develop broader strategies that defend the interests of the workers, involving new concepts like industrial democracy and corporate social responsibility [CSR]. These are all challenges confronting the tea industry in Darjeeling today. The dimension of the structural readjustment that is needed within the tea industry to cope with them needs to be analysed immediately.

\section{ELEMENTS OF ANALYSIS}

Commercial tea plantations in the Darjeeling hills were established in sequential waves of expansion, commencing from the late 1850 's. The initial tea estates were thus mostly located in the original Darjeeling Tract that had been acquired in 1835. Subsequent expansion brought plantations into being on both sides of the Balasun Valley, the western part of which was annexed after the Anglo-Sikkim War in 1850. Through the 1860's, the attention of the planters shifted to the Terai and Dooars. After a new Forest Act was passed in 1927, new hill areas located mostly within Kurseong sub-division became available for new tea plantations.

The patterns of recruitment of plantation workers followed the sequence of expansions, and were echoed in the resulting community patterns of migration. Each migration wave was drawn from a different area within the supplying regions, which in the regions of hill plantations were located in eastern and central Nepal. It is therefore of interest to study the current community distribution of tea workers.

Socio-economic conditions among tea workers were recorded through information on current wage and non wage benefits, working hours (including domestic work for women workers), as well as housing and medical benefits. The provision of non wage benefits such as rations, free fuel, electricity and labour housing reflected the present state of implementation from the Plantation Labour Act in the hill tea plantations. Information on health conditions included the type of health services sought and the modes in places of treatment, classified in terms of whether these were provided by the plantation management or were privately sought outside the plantation at Government health facilities, etc. The primary information on educational standards and aspirations within the plantation communities were also classified in terms of whether these were provided within the plantation or outside.

\section{Review of Literature}

Although the main concern of the present study is the changing labour economics of the tea industry in Darjeeling, the number of critical studies on labour situations in the Darjeeling tea industry is relatively 
few. Literature sources however exist, covering aspects relevant to the current tea situation in India. Several of the early sources are of a technical nature, covering the practice of tea planting, without much critical comment. Eden (1965) thus provides a descriptive account of the various stages of tea cultivation and manufacture. Similarly, Harler (1966) provides detailed information on the phases of tea planting operations.

A critical attempt is made in Savur (1973) to show how labour, particularly that of female tea workers, creates surplus value in the tea industry by (a) unfair production methods used to escalate the productivity of labour; and (b) underpayment of due wages.

From a more macro perspective, Rao \& Hone (1974) examine the impacts of policy failures within the tea sector in India during the 1960s and 1970s. In this light, they also suggest remedial measures that would enable the Indian tea industry to expand its output for both domestic and international markets, while simultaneously pursuing the negotiation of new international tea agreements which would to regulate the export availability of tea and raise its market price.

Awasthi (1975) analyses several economic aspects of the tea industry in India, with special reference to the Assam plantations, covering the channels of tea production and distribution. His study is based on field surveys as well as on economic and statistical information drawn from official reports, records and journals. Within the present Indian context, with the rapid growth of the international tea production and increasing competition from other tea-producing countries like Sri Lanka and the East African nations, the study assumes great significance.

Based on the findings from extensive fieldwork conducted among tea plantation workers in the Dooars in North Bengal, Bhowmik (1980), analyses social and production relations within the tea industry. While the structure of such socioeconomic relations has changed since the early days of colonial plantations, the extent of change has been determined contextually by the isolation of the tea plantations from the wider social system, the influence of working class organisations among tea workers, and the intermediating role of the state. Das Gupta (1981) examines similar questions historically, dealing with the formation and development of labour market structures in India with particular reference to three major colonial industries, namely tea plantations, coal mines and jute manufacturing, all of which were established with a strong base in eastern India.

In a more focused regional context, English (1985) presents an overview of the cultural and economic history of the Himalayas. The growth of the trans-montane trade, the development of intensive agriculture, and the distribution of ethnically diverse populations throughout the region are tied to the formation of successive Hindu and Buddhist states. Of central concern are the processes by which the Himalayan region was integrated into the colonial economy of British India during the nineteenth century.

Behal (1985) deals with the evolution of a plantation structure in the nineteenth century tea plantations in the Assam Valley, focusing on worker exploitation. The study also examines the genesis of labour resistance and protests and the different forms these assumed over time, exploring existing hindrances to the development of class consciousness among plantation workers.

Das Gupta (1986) examines the historical evolution of the plantation labour system in several parts of Assam. The study analyses the transfer of certain sections of the population from a variety of noncapitalist occupations to the command of capital, through the labour process created on the plantations, and the nature and maintenance of civil authority in plantation regions. The process of production of 
plantation crops and the reproduction of labour power are also examined in terms of the nature and extent of proletarianisation. The study also touches upon the larger theoretical implications of the empirical data it presents, such as the symbiotic relationship between such deliberately-created subsistence economies and capitalist sector.

Some of the basic problems experienced by the tea industry in India and particularly in northern West Bengal are identified by Misra (1986), drawing upon several sources of published as well as unpublished data available both at State and district levels. The study also utilises primary data collected in the Terai, Dooars and Darjeeling plantation regions.

Several papers in Sarkar \& Lama (1986a) discuss environmental and economic aspects of the regional economy of the Darjeeling hill region. Other papers in Sarkar \& Lama (1986b) examine wages, industrial relations, management and employment patterns, labour productivity, trade unions within the regional tea industry. The socioeconomic condition of the tea workers are also examined in relation to the statutory provision of labour benefits to tea workers, to arrive at an assessment of living standards of plantation labourers in the Darjeeling hills.

Ghosh (1987) studies long-term proliferation of the tea industry in India in relation to various Government initiatives, utilising the information available in Government records. The history of land management rules, regulations acts, land utilization, revenue patterns and the land resumption policy of the State Government, in relation to the tea estates in West Bengal are discussed at length.

Mitra (1991) re-examines the early expansion of tea cultivation in Assam, followed by the establishment of tea plantations in the Darjeeling, Terai, and the Dooars regions of North Bengal, as well as the Nilgiris and other tea-growing districts of South India. Relatively recent developments within the Indian tea industry are also focused upon in the subsequent discussion, which examines the characteristics of the tea industry in respect to tea production, demand and exports, and the nature of the domestic and global tea market. An analytical framework is proposed, within which the problems of the tea industry may be studied consistently, along with suitable policy prescriptions.

Das Gupta (1994) makes an assessment of the social security and insurance arrangements prevailing in India during the colonial period with regard to factory workers. Focussing on the uncertainties and adversities faced by the urban-industrial workers, the analysis touches on some of the broader dimensions and distinguishing patterns of the processes of proletarianisation in India and other countries of the third world.

Dasgupta (1996) discusses the early development of the tea industry in Darjeeling and the Dooars, examining the growth of the tea labourforce, the conditions of plantation labourers, the origin of the trade union movement on the plantations, structural evolutions in tea estate management, and the special situation of women labourers in the tea estates. The influence of labour productivity on the wages of tea workers is also examined. A review of the changing labour market trends and workers' living standards which have accompanied the changing patterns of global trade is provided in Mazumdar (1997), which reviews these factors in the lights of the World Development Report 1995 (WDR 1995).

Dwivedi (1999) makes a detailed study of regional differences in tea production situations in different tea growing regions of India. The study aims to identify the technical and economic factors that are responsible for such variations, using published and unpublished data as well as primary data collected directly from selected tea estates, for the first time presenting a systematic and scientific analysis on the impact of the age of tea bushes on tea yields. 
Sharma (1999) also studies the Indian tea industry and its future prospects. The study observes how the tea industry has consistently had to face setbacks in global markets because of rising competition from new tea-producing countries which are more favoured by their productivity levels, quality standards and cost structures. The need for restructuring within the Indian tea industry is also noted, in order to compete efficiently with these new challenges.

More recent trends within the Indian tea industry are reviewed in Sankrityayana (2006), which makes a detailed examination of the current labour situation on the West Bengal plantations of West Bengal against the backdrop of the global economic changes that have hit the Indian tea industry. The reasons for the present crisis in the tea industry are also identified, particularly in terms of the impact they have had on plantation workers.

\section{Objectives of the Study}

The proposed study is primarily concerned with an assessment of the socio-economic condition of the tea garden workers in the Balasun Tea Estate in the District of Darjeeling. The main objectives of the study are:

To evaluate the impact that tea plantations have had on the livelihood of the workers, ever since tea continued to act as the backbone of the local economy for their livelihood.

$\square$ To analyze the role and responsibility of the labour unions for the development of the workers, with special reference to the role of women in tea production and their participation in trade unions, cooperatives and other organizations.

$\square$ To check the liability of the central and the state governments for their inaction and apathy in setting up the committee to revise the minimum wages for the workers since 1957 and securing the rights of the workers.

$\square$ To assess the struggle for survival of the workers in the closed and abandoned tea gardens that led to hunger, starvation, electricity and water being cut-off.

\section{Profile of Survey Area}

1. Tea Estate: Balasun Tea Estate.

2. Block: Sukhiapokhri.

3. Gram Panchayat: Gorabari, Sonada.

4. Distance from the Nearest Town: $11 \mathrm{~km}$.

5. Nearest Village: Margaret's Hope.

The name of the selected estate is Balasun Tea Estate. It lies in the Kurseong sub-division of the Darjeeling district. The Estate is run by Jayshree Tea and Industries Limited. According to the primary data collected from the office of the tea estate, the total processed area or Grant area (Hect) of the estate is 375.97 hectares, of which the area under tea is 181.38 hectares. For the year 2004, the productivity statistics was $293281 \mathrm{kgs}$ annually, where the proposed statistics stood around 80,000 kgs. The total despatches of tea i.e., through auctions, exports and private sales were $287013 \mathrm{kgs}$. The tax and duties to be paid amounted 
to ₹ 330426.27. The total number of daily workers for adult male was 182 and the same for adult female was 368. The approximate number of the families residing in the tea estate was 2840 families.

\section{SURVEY METHODOLOGY}

Basically, the approach adopted while doing the research was by using both secondary and primary data. The empirical study that forms the focus of the present paper is centered on the main factor of production within the tea industry, namely the labourforce and its present labour condition. We have selected a sample of labourers from one of the tea estate in the hills of Darjeeling. For obtaining primary data, the selected respondents were approached for direct interviews based on a structured questionnaire. The respondents for the sample survey were drawn from a tea estate selected randomly within Darjeeling.

In the first phase of the survey, 30 labour households were selected from the entire tea garden. Since, the households are selected randomly; they could either be male-headed or female-headed. We have categorised the samples into different groups according to the working profile, migration history, income and asset profile. The questionnaire enabled the collection of general and other information on the worker families, their working profiles and dependency patterns, their migration history, their income \& assetholding profile, as well the extent of ration benefits, housing benefits, educational benefits and medical benefits being provided currently to them in terms of the Plantation Labour Act.

The official records and other secondary sources were utilized which have duly been acknowledged for securing the secondary data. The research study thus draws upon several sources of data, published as well as unpublished, available at the district as well as the State levels. The preceding secondary study was supported by economic and statistical information contained in official reports and records, journals and other literature sources.

\section{WORKER UNIONS ON THE ESTATE}

The estate is under the Darjeeling Terai and Dooars Plantation Labour Union. The union was established in November, 2007. In the tea gardens the unions are formed by the ruling party. The main demands of the union are to provide labour housing to the workers and make new labour appointments. Since, the Plantation Labour Act 51 mandates that the estate provide and maintain a rent free covered labour housing area approximately $47 \mathrm{sq} \mathrm{m}$ of durable construction to every resident worker family. The union fights against the estate regarding such rights of the worker of which they are deprived for.

\section{FINDINGS AND ANALYSIS FROM THE SURVEY STUDY}

According to the survey report, there are variations regarding the workers general information, family description, migratory history, income and in many more ways. We have the other two categories of the workers (respondents) viz. male workers and the female workers.

Age Group: From the survey report, it is seen that $50 \%$ of the workers belong to the age group of $30-$ 40 years, and then the other group belonging to age group of $40-50$ years is about $30 \%$. The workers belonging to $20-30$ and $50-60$ age groups are least. This shows that the workers are in the most productive stage of their age. They get retired by the time they reach the 60 's. 
Community: It was found from the survey that the workers belonged to different community. The most common were the Scheduled Tribe with more than $60 \%$, then there is the Other Backward Class with $30 \%$, and then General category about $6 \%$ and the least is the Scheduled Caste. There are no other type of community apart from the four.

Level of Education: It was found that most of the workers have attended the school though have never reached above class 4 . This was due to the negligence of their parents who were illiterate or may be due to the children who were never interested in studying. Since there was no example of an educated person who had got better jobs, this also discouraged the workers. This again proved that there exists educated unemployment in the gardens.

Migration History: It was found that most of the workers have been residing in the estate for more than three generations. The ancestral place of residence before migration was found to be Nepal for all the workers. The original occupation of the workers family before the migration was agriculture for all. This shows that in the tea gardens the farming structure of the workers has changed to labour structure. The social structure of the workers was cut-off because of the migration.

Outmigration for Work: It has been found from the survey record that most of the migrants belong to age group of 18 to 35 years. The members who have migrated are to a large extent lees qualified and they are engaged in low standard jobs like waiter in the hotels, security guards and other small factory jobs. There is no proper provision of new employment oppertunities in the estate for the welfare of the workers

Working Profile: Looking at the working profile of the workers, it was found that they are permanent workers in the garden. Most of the workers age at the entry was 18 and above. For the elder age group workers, who have reached 50 and above the age at entry was found to be 12 and above. This shows the child labour which was prevalent in the gardens only during the early period.

The current daily wage rate of the workers was ₹ 58, and this wage varies for the male workers depending upon the post of the worker i.e. department wise. Some are engaged in spraying the fertiliser, pesticides, some in the vehicle for uploading and down loading the tea leaves, etc. This makes the daily wage of the males to vary and it is called 'Pay of Post'. For the female worker, it varies during the peak season, specially between April to September, when the plucking of tea leaves is regular and in large scale. They are given a daily plucking task which varies from $10 \mathrm{~kg}$ to $25 \mathrm{~kg}$ during the peak season.

Standard Work-day Timings: The survey report suggests that the departure time for work was 6 a.m. in the morning, the arrival at the work place was at 7 a.m, they have lunch-break from 11:30 p.m. to 12:30 p.m., then the evening shift starts from 1p.m., they depart from work at 4p.m and finally they reach home at around 4:30 p.m. So, the total hour that they spent at the field rounds to about 7 hours. The workers return home after working for seven hours, which makes their whole day in the field from the early 6 a.m. to 4:30 p.m. The male workers they often take rest after the return, only few they have to fetch fodder, else they enjoy the leisure. While the female workers have to do the cooking, washing, take care of children/elders, cleaning, they get time to enjoy the leisure.

Income \& Asset Profile: The report on the income and asset profile showed that the workers equally belonged to both the APL and BPL categories. The main income source of the family income was the regular wages. Only few family had other sources like remittance income and enterprise activity. The workers in the garden also had occasional income sources like sale of fruits and petty trade. There are less number of shops in the garden which shows that the income of the workers are not enough to spend on extra economic activities. 
It was observed that $25 \%$ of the workers annual income belonged to ₹ 30,000 to ₹ $40,000,23 \%$ of the workers annual income was between ₹ 10,000 to ₹ 20,000 , rest of them belonged to above either the higer group or for the average.

The consumption level of the workers was found to be average type. We can predict that the most part of the workers income are consumed either for food or clothing and shelter. They have a very low record of saving

The estate gives the worker a rent-free land where workers have built their house. The land ownership actually belongs to the estate. The estate pays the revenue for the land to the government so they can at anytime make the labour landless. This proves the insecurity of the workers in the plantations.

Most of the workers were found to have household white goods like T.V. sets and C.D. players, few of them possessed cell phones too. The workers work hard for earning extra, they hold live stock assets like cattle, goat, pigs and poultry birds. This are used for self-consumption or rather for sale sometimes. But from the survey it was found that the workers mainly avoid selling.

Ration Benefits: Despite of the wage in cash, the workers are also given wage in kind. A permanent worker and his sons or daughters who are dependents are provided with subsidised rations. The permanent resident workers and the bona fide dependents upto the age of 16 years are admissible for such benefits. One permanent worker gets $2 \mathrm{~kg}$ rice and $4 \mathrm{~kg}$ atta/wheat. The dependents get half the amount of the permanent worker. The workers are not satisfied with the amount of the ration they receive. There is a requirement for the upgrading both the quality and quantity of the ration received by the workers.

Housing Benefits: The report on the housing benefits showed that none of the workers have till date received the labour housing facility. According to the Plantation Labour Act, the estate has to provide the households with housing benefits which is nil in the present estate. This shows the extent of the PLA is not being implied in the gardens.

It has been found from the survey that $56 \%$ of the workers possessed pucca type housing, $34 \%$ of them have semi-pucca and the rest have the kuchcha type. The workers have kitchen and toilets. Their main drinking water source was the Jhora water. Firewood is the main source of fuel for the workers in the tea garden. Only few workers use kerosene and LPG as a secondary source. The estate provides firewood for the workers annually. Each worker gets $320 \mathrm{~kg}$ firewood annually, which they get in the cash form. For each worker gets ₹ 240 p.a. The supply offirewood is not sufficient for the workers as they require more than the given amount, for this reason they go to the jungles to collect firewood. This leads to exploitation of the jungles, deforestation and in some way hampersthe environment.

Educational Benefits: The survey report shows that the workers children in the estate have the facility of government primary schools. The workers are not satisfied with the education standard of the schools in the estate, they want their children to study in English schools, but because of their poor income they are unable to do so. The workers want their children to study till graduation and even more than that, since, they have realised that it was because of their illiteracy, they are being exploited. While none of the workers were willing to let their children work in the garden and be like them. The reasons were simply poor opportunities, poor income, poor career advancement, and poor exposure.

This situations makes us think that as the workers are being conscious in such matters, will the estate in the hills face the labour shortage in the future? The question arise regarding the workers coming generations, whether their children will work in the estate or they will not. If not then what will happen 
to the estate, or the land on which they are living. There are certain number of questions that arise. There are justification needed to solve such questions before its too late.

Medical Benefits: As per the report on the medical benefits, we found the sick workers belong to older age group and in some cases the younger ones get due to some reasons. The workers in the garden are dependent on Modern Allopathy for the type of treatment. They used to apply Shamanist and Traditional medicines type before but now they have started shifting from the type of treatment they used to follow in the sense they have becoming modern in their thoughts. The workers in the estate choose the first place for treatment outside the garden hospital. The survey finds out that they either go to the Government Health Centre, Private Clinic or to the Nursing Home

\section{GENERIC INFORMATION}

According to the information gathered from the tea estate as common information, the management provides certain benefits to the workers of the tea garden. The Estate provides the paid leave 'Hakchhutti' for the labourers which are calculated as 20 working day equal to one day earned leave. The labourers get extra reward 'Bakshish' by the managers according to the quantity of work that is done above the task given. Other worker facilities like aprons, umbrella, protective cloth, Foot-wear, Firewood, proper ration and bonus are made available to the workers by the estate. Footwear firewood and bonus are provided every year and aprons, umbrella, protective cloth every two years.

\section{CONCLUSION}

Labour on the plantations is applied in large doses at specific points of production cycle to deliver an unbroken flow of pre-processed green leaf to the estate factory throughout the production season. Hence, this makes the labour an important aspect for the tea industry. If the labour is productive and efficient, the industry will benefit more. But the workers in the tea industry are the most exploited and treated as 'human machines'. There should be some legal steps for their security so that they may reflect the positive returns through the increasing productivity and hence, the increase in the foreign exchange.

The Tea Act of 1953 mandates the Indian Tea Board for the implementation of Plantation Labour Act 1951 and the plantation rules in any tea growing areas for monitoring the labour standards. Despite of such steps by the government for the betterment of the workers, the status and work roles of the plantation labour at the basic rung of the plantation system have, as a result, undergone little change and the modes of worker management are still essentially the same.

As far as the sample garden is concerned, the modes of provision are not fulfilled properly. The workers are not getting proper labour housing benefits; proper medical facilities; and likewise many other benefits. They are exploited in case of wages and salaries. In comparison to the hours of work and the type of work that they do, with the other types, they have to work even more and they imply heavy physical pressure. Inspite of such heavy task, the workers are unable to reap justifiable wage till date. The garden healthcare facilities are not sufficient in case of serious illness. They feel and even know that they are being deprived by the management yet they are unable to raise voice against them. If they do so they will be punished in different manners, directly and indirectly. This position of the workers gives us the clear picture of the situation of the present workers that they are not independent even today. They have to survive the cruel nature of the management. 
The union exists in the garden but, according to the view of the workers against the union's work, is that, the union has been unable to make a great improvement for the welfare of the workers, Since, there are no any such steps that has been taken by the union for the sake of the workers. This failure of the union makes sense for the union members to work with effectively, so that the workers may feel the difference. Thus, we finally conclude with the survey report saying that the condition of workers in the Darjeeling Tea Industry till date has not changed. They were deprived and used by the management before two-three decades to reap profits and still today they are being used. The workers in the tea gardens are inherently bearing the cruel nature of the managers. Though they are raising voice against the authority and the government too is trying to help out the working class, yet there lays a gap between the regulations and the application of such. In conclusion it may be said that, the Tea community are highly deprived in all respects of socio-economic and political aspects. Therefore, it is a high time for the government as well as the owners and management to come forward and uplift this particular society. Otherwise this section of our society remains static. Hence, there is an immediate need to seek better lookout for the condition of the plantation labour in the hills before the inefficiency of the labourers may turn into stagnation of the Tea Industry in Darjeeling.

\section{REFERENCES}

1. Agarwala, A.N. 196. 'The Social Security Movement in India', The Economic Journal, 56(224): 568-582.

2. Awasthi, R.C. 1975. Economics of Tea Industry in India with special reference to Assam, United Publishers, Guwahati.

3. Banerjee, Debdas. 1999. Colonialism in Action, Trade, Development and Dependence in Late Colonial India, Orient Longman Limited, New Delhi.

4. Behal, Rana Pratap. 1985. 'Forms of Labour Protest in Assam Valley Tea Plantations, 1900-1930', Economic and Political Weekly, XX(4): PE19-PE25.

5. Bezbaruah, H.P. 1999. 'Origin and History of Development of Tea', Global Advances in Tea Science, pp. $383-392$.

6. Bhaduri, Amit. 2006. Development with Dignity, National Book Trust, India.

7. Bharali, Gita 200. 'Labour Unrest and Social Insecurity of Plantation Workers: A case Study, Seminar on Labour and Employment Relations in Plantations in a Globalising Economy, Guwahati: V. V. Giri National Institute and OKDISC, March 9-10.

8. Das Gupta, Ranajit. 1981. 'Structure of the Labour Market in Colonial India', Economic and Political Weekly, Special €Number 16(44/46): 1781-1806.

9. Dasgupta, Manas. Economic Development of Darjeeling Hill Areas; Problems and Prospects, Uttar Publications Pvt. Ltd., Calcutta.

10. Dash, A.J. 1947. Bengal District Gazetters: Darjeeling; Bengal Government Press, Calcutta.

11. Dwivedi, H.N. 1999. Production of Tea in India with special reference to Dooars, K.P Bagchi \& Company, Calcutta. 
12. Eden, Thomas. 1965. Tea, Longmans, Green and Co., London.

13. Ghosh, Tushar Kanti. 1987. Tea Gardens of West Bengal - A Critical Study of Land Management, B.R. Publishing Corporation, Delhi.

14. Harler, C.R. 1996. Tea Growth, Oxford University Press, London.

15. Mitra, Neelanjana. 1991. 'Indian Tea Industry: Problems and Policies', Economic and Political Weekly, 26(48): M153-M156.

16. Misra, Sib Ranjan. 1986. Tea Industry in India, Asish Publishing House, New Delhi.

17. O’Malley, L.S.S. 1947. Bengal District Gazetters, Darjeeling, (reprint), Logo Press, New Delhi.

18. Ortiz, Sutti; 2002. 'Labouring in the Factories and in the Fields', Annual Review of Anthropology, 31: 395-417.

19. Pradhan, Kumar. 1982. Pahilo Pahar, Shyam Brothers, Darjeeling.

20. Rao, K.B.K and Hone, Angus. 1974. 'India and the World Economy', Economic and Political Weekly, 9(28): 1111-1118.

21. Raman, K. Ravi. 1986. 'Plantation Labour: Revisit Required', Economic and Political Weekly, 21(22): 960-962.

22. Ray, C.R. 1936. 'Plantation Economy', The Economic Journal, 46(184): 620-644.

23. Sankrityayana, Jeta. 2006. 'Plantation Labour in The West Bengal Tea Industry', chapter ILO: Productivity and Decent Work in the Tea Industry in India - Proceedings of a Consultative Meeting, International Labour Organisation.

24. Sarkar, Bidyut; Tea in India 1984. Consultative Committee of Plantation Associations (CCPA), Calcutta.

25. Sarkar, R.L. and Lama, M.P. 1986a. The Eastern Himalayas Environment and Economy, (Indian Institute of Hill Economy, Darjeeling), Atma Ram \& Sons.

26. Sarkar, R.L. and Lama, M.P. (eds) 1986b. Tea Plantation Workers in the Eastern Himalayas - A Study on Wages, Employment and Living Standards, (Indian Institute of Hill Economy, Darjeeling), Atma Ram \& Sons.

27. Savur, Manorama; 1973. 'Labour Productivity in the Tea Industry', Economic and Political Weekly, 8(11): 551-559.

28. Sharma, Khemraj. 1999. Tea Industries in India - An Introduction, N.L. Publishers, Dibrugarh.

29. Sen, Amartya. 1999. Development as Freedom, Alfred A. Knopf, Inc., New York.

30. Tea Board; 1982. Tea Directory: India, Tea Board of India, Calcutta.

31. Tea Board; Tea Statistics, Tea Board of India, Calcutta, various years.

32. www.google.com, www.jstor.org

33. http:/ Darjeeling.go.in/darj-hist.html

34. www.indiateaportal.com 
